\title{
The Neuropeptide Egg-Laying Hormone Modulates Multiple lonic Currents in Single Target Neurons of the Abdominal Ganglion of Aplysia
}

\author{
Rene F. Jansen and Earl Mayeri \\ Department of Physiology, School of Medicine, University of California, San Francisco, California 94143
}

The bag cell neurons of the abdominal ganglion of Aplysia are a useful system for the study of peptidergic neurotransmission. A 20 min burst of impulse activity in the bag cells induces or augments repetitive firing in LB and LC neurons in the abdominal ganglion for up to several hours. Previous experiments have indicated that this effect is mediated by the putative bag cell transmitter egg-laying hormone (ELH). Using voltage-clamp analysis we found that bag cell bursts (BCBs) evoke long-lasting changes in membrane current in these neurons that are mimicked by the application of ELH. The combined ELH-evoked current is inward at all membrane potentials between -110 and $-10 \mathrm{mV}$ and consists of 3 separable currents persisting for 30-120 min. They include (1) a depolarizing current that is activated at membrane potentials above $-40 \mathrm{mV}$. This current, termed $I_{\mathrm{s} \text {, }}$ is blocked by prolonged exposure to $10 \mathrm{mM} \mathrm{Ni}{ }^{2+} / 0 \mathrm{mM} \mathrm{Ca}^{2+}$ and is not abolished by $0 \mathrm{mM} \mathrm{Na}{ }^{+}$or $100 \mathrm{mM} \mathrm{TEA}+0 \mathrm{mM} \mathrm{Na}^{+}$in the bathing medium. It is therefore a $\mathrm{Ca}^{2+}$-sensitive current and does not involve $\mathrm{Na}^{+}$as a charge carrier. (2) There is a hyperpolarizing current that is activated at membrane potentials below approximately $-70 \mathrm{mV}$. This current, termed $I_{h}$, is blocked by external $\mathrm{Rb}^{+}(5 \mathrm{~mm})$ and $\mathrm{Cs}^{+}(10 \mathrm{~mm})$ and has a chord-conductance that shifts with the external [ $\left.\mathrm{K}^{+}\right]$ according to the Nernst potential for potassium. It is therefore an inwardly rectifying $\mathrm{K}^{+}$current. (3) There is a small, steady depolarizing current, termed $I_{x}$. This current is the only one that remains after prolonged exposure to $10 \mathrm{~mm}$ $\mathrm{Ni}^{2+} / 0 \mathrm{mM} \mathrm{Ca}^{2+}$-containing bathing medium. It is $\mathrm{Na}^{+}$dependent and is associated with a small increase in membrane conductance that is largely independent of membrane voltage. All 3 currents are slow to inactivate; they appear to sum algebraically to produce the net BCB- or ELH-evoked current.

Various neuropeptides have been found in the CNS of vertebrates and invertebrates, and peptides are widely accepted as potential neurotransmitters (Krieger, 1983; Iversen, 1984; Schmitt, 1984; O'Shea and Schaffer, 1985). However, relatively little is known about their exact physiological roles or their cellular mechanisms of action. From studies in identified peptidergic systems, where the effects of the application of peptide

\footnotetext{
Received Oct. 12, 1987; revised Dec. 21, 1987; accepted Dec. 28, 1987.

We thank Richard O. Brown and Shaul Hestrin for helpful comments on the manuscript. R.F.J. was supported by the Netherlands Organization for the Advancement of Pure Research (Z.W.O.). The research was supported by NIH Grants NS 16490 and NS 16033 to E.M.

Correspondence should be addressed to Dr. E. Mayeri at the above address. Copyright (C) 1988 Society for Neuroscience $0270-6474 / 88 / 083074-11 \$ 02.00 / 0$
}

can be compared with the neurally evoked response, it is clear that the actions of some of these peptides are distinct from those of "classical" neurotransmitters in that peptides can modulate electrical signaling for seconds, minutes, or longer (Branton et al., 1978; Jan and Jan, 1982; Konishi and Otshuka, 1985; Sigvardt et al., 1986). We studied the long-lasting changes in ionic currents that are caused by the release of the neuropeptide egglaying hormone (ELH) from the bag cell neurons of the marine mollusc Aplysia.

The bag cells are neuroendocrine cells that release 4 neuroactive peptides derived from a common precursor protein (Stuart and Strumwasser, 1980; Scheller et al., 1983; Rothman et al., 1985; Brown and Mayeri, 1986; Sigvardt et al., 1986). These bag cell peptides are released during a 20-30 min period of repetitive, high-frequency impulse activity. In vivo such bag cell bursts (BCBs) invariably precede a stereotyped behavior called egg-laying (Pinsker and Dudek, 1977). One of the released peptides, ELH, is a 36 amino acid peptide that fulfills almost all the strict criteria for transmitter identification (Branton and Mayeri, 1978; Branton et al., 1978; Mayeri et al., 1979a, b; Stuart and Strumwasser, 1980; Mayeri and Rothman, 1982; Mayeri et al., 1985). ELH is a wide-acting neuropeptide that acts directly on the ovotestis (Rothman et al., 1983b) and on different parts of the CNS (Branton and Mayeri, 1978; Branton et al., 1978; Stuart and Strumwasser, 1980) at the initiation of the egg-laying behavior (Cobbs and Pinsker, 1982a, b; Ferguson et al., 1986).

The bag cells are organized in 2 clusters of about 400 neurons each, located at the rostral margin of the abdominal ganglion. Previous investigations indicate that ELII is released from the bag cells' axons into interstitial and vascular spaces of the abdominal ganglion, where the peptide diffuses a relatively long way (up to tens of microns) to $\mathrm{LB}, \mathrm{LC}$, and $\mathrm{R}_{15}$ target neurons and induces or augments repetitive spike activity for up to several hours (Branton and Mayeri, 1978; Branton et al., 1978; Mayeri et al., 1979a, b; Mayeri and Rothman, 1982; Mayeri et al., 1985). Application of ELH to buccal neuron $B_{16}$ of the buccal ganglion also induces repetitive firing (Stuart and Strumwasser, 1980; Ram, 1983; Kirk and Scheller, 1987).

To further identify ELH as neurotransmitter in the abdominal ganglion, we studied the ionic mechanisms that underlie responses to neurally evoked release and to application of ELH to LB or LC target neurons in the abdominal ganglion. These neurons include siphon, kidney pericardial and vasoconstrictor motorneurons (Koester and Kandel, 1977), and they have been established as target neurons for ELH (Mayeri et al., 1979b). We found that the ionic mechanism of the neurally evoked 
response is apparently identical to that of ELH action and that the response involves at least 3 different currents. These currents differ from the current modulated by ELH in the buccal neuron $\mathbf{B}_{16}$ (Kirk and Scheller, 1986). Parts of this study have been published in abstract form (Jansen and Mayeri, 1986, 1987).

\section{Materials and Methods}

Animals and dissection. Abdominal ganglion were dissected from sexually mature Aplysia californica weighing $200-400 \mathrm{gm}$, obtained from Sea Life Supply (Sand City, CA). The connective tissue sheath overlying the left hemiganglion was removed, and cells on the dorsal surface of the left lower (caudal) quadrant, which includes the LB and LC neurons, were axotomized by cutting the commissure and the genital-pericardial nerve with a razorblade scalpel. In some preparations an additional cut between the left upper and left lower quadrant of the abdominal ganglion was made. The isolated cluster of cells corresponded to the caudal- and medial-most group, which were all usually responsive to ELH and bag cell discharges. The preparation was kept at room temperature (20$22^{\circ} \mathrm{C}$ ); the animals were kept at $19^{\circ} \mathrm{C}$.

Bag cell stimulation. BCB discharges were triggered by brief extracellular electrical stimulation via an electrode placed on the cell bodies of the left bag cell cluster (Mayeri et al., 1979a). A 1-2 sec train of 5 msec pulses was applied at a rate of $5 / \mathrm{sec}$ through a constant-current device. Bag cell spike activity was monitored by switching the stimulating clectrodes on the bag cell cluster to an $\mathrm{A} / \mathrm{C}$ amplifier. In some experiments, BCBs were triggered by extracellular stimulation of the pleural-abdominal connective. In those experiments, the pulse duration was $0.5 \mathrm{msec}$, and bag cell activity was monitored with an extracellular electrode placed on the bag cells. The LB or LC cell was released from voltage clamp for a short period during bag cell stimulation. The longlasting nature of the responses to BCBs and ELH applications usually do not permit the triggering of more than one $\mathrm{BCB}$ or more than one ELH application in a given preparation.

Data collection and analysis. Cells were voltage-clamped with a 2-electrode system (Dagan 8100). Cells were penetrated with one electrode to record the membrane potential and a second electrode to pass current. The electrodes were filled with $2 \mathrm{M} \mathrm{KCl}$, and the current electrodes had resistances of 1-2 M $\Omega$. The electrodes were shielded with aluminum foil to within $1-2 \mathrm{~mm}$ of the tip. This shielding method results in capacitive transients that typically last less than $1-2 \mathrm{msec}$. The membrane potential was measured differentially with respect to a second microelectrode positioned close to the ganglion. The drift in the voltage recording system was typically less than $1 \mathrm{mV} / \mathrm{d}$. The preamplifier had a high-frequency cutoff of $30 \mathrm{kHz}$. The membrane current was measured with a virtual ground circuit that was connected to the recording chamber through an $\mathrm{Ag}-\mathrm{AgCl}$ half-cell. No compensation for series resistance was made. In the ramp mode, the monitored current was filtered with a low-pass filter with a high-frequency cutoff of $13 \mathrm{~Hz}$, except for the data shown in Figure $3 C$, which was filtered at $30 \mathrm{~Hz}$. In the square-wave mode, the current monitor filter had a high-frequency cutoff of either $3 \mathrm{kHz}$ or $300 \mathrm{~Hz}$. The data were digitized with a 12-bit analog-to-digital converter (Labmaster, Scientific Solutions) using a sampling interval of $55 \mathrm{msec}$ (ramp mode) or $1.0 \mathrm{msec}$ (square-wave mode). Capacitive transients were measured using sampling intervals of 0.04 msec. Data acquisition and analysis were done using Pclamp software (Axon Instruments, Burlingame, CA) and an IBM PC-AT computer.

Depolarizing ramp command voltages between -110 and $-10 \mathrm{mV}$ were applied every $2.5 \mathrm{~min}$ (Fig. 1). The rate of change of the membrane potential was $6.6 \mathrm{mV} / \mathrm{sec}$. Stability during the ramp experiments was

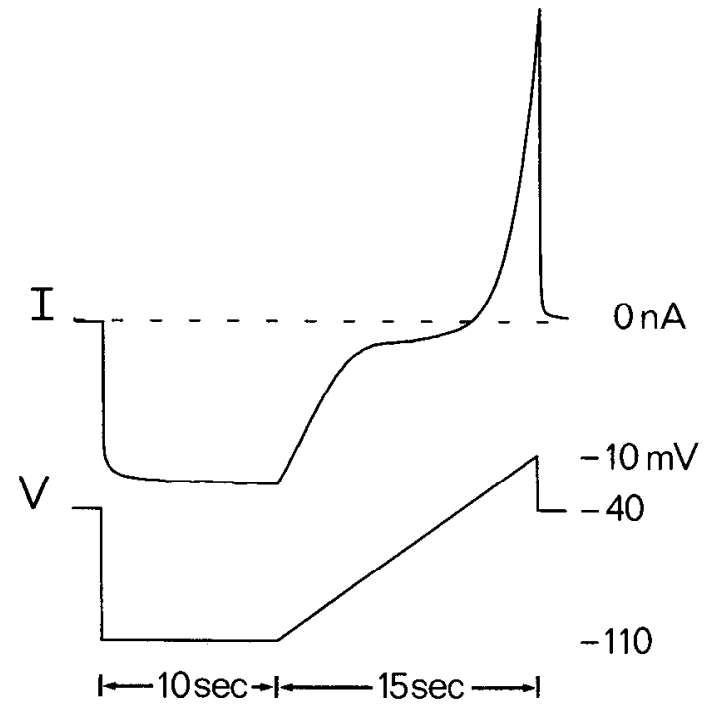

Figure 1. The ramp command potential used in most experiments and the current produced in a LB or LC neuron. The membrane potential was stepped from a holding potential of -40 or $-50 \mathrm{mV}$ to $-110 \mathrm{mV}$, where the cell was held for $10 \mathrm{sec}$. The ramp command had a duration of $15 \mathrm{sec}$ and depolarized the membrane with a rate of $6.6 \mathrm{mV} / \mathrm{sec}$ to $-10 \mathrm{mV}$. At the end of the ramp, the membrane potential was stepped back to the holding potential. Note the marked inward rectification of the current below about $-70 \mathrm{mV}$.

monitored by plotting superimposed current sweeps on a Hewlett-Packard $7470 \mathrm{~A} X-Y$ plotter. For analysis, multiple successive $I-V$ relations obtained immediately before application of peptide or triggering of a bag cell burst (indicated as "baseline") were averaged. Evoked currents were then obtained by subtraction of this averaged baseline from $I-V$ relations generated after a BCB was triggered or peptide was applied. Families of square-wave voltage commands were similarly applied at regular intervals, usually $2.5 \mathrm{~min}$. Averaging and subtraction methods were the same as for ramp experiments.

Solutions. ELH was purified from homogenized bag cell clusters by HPLC (Rothman et al., 1985). A polyethylene pipette (diameter $\sim 100$ $\mu \mathrm{m}$ ) was used to apply $10 \mu \mathrm{l}$ of ELH (concentration in pipette, $100 \mu \mathrm{M}$ ) to the abdominal commissure area exposed by the axotomy. Prior to the actual experiment, the recording chamber $(\sim 1 \mathrm{ml})$ was perfused steadily with artificial seawater (ASW, Instant Ocean), and perfusion was stopped when the experiment was started. In control experiments, stopping the perfusion or applications of ASW never produced the longlasting effects of BCBs and ELH. The compositions of the bathing media are shown in Table 1.

\section{Results}

$B C B$ s and ELH cause apparently identical changes in membrane conductance

The bag cell neurons are normally silent. When a brief electrical stimulus is applied to 1 of the 2 bag cell clusters, the bag cells

Table 1. Composition of bathing media

\begin{tabular}{|c|c|c|c|c|c|c|c|c|c|c|c|}
\hline Solution & $\mathrm{KCl}$ & $\mathrm{MgCl}_{2}$ & $\mathrm{CaCl}_{2}$ & Tris & TMACl & HEPES & TEACl & $\mathrm{CoCl}_{2}$ & $\mathrm{NaCl}$ & $\mathrm{RbCl}$ & $\mathrm{Na}_{2} \mathrm{SO}_{4}$ \\
\hline ASW & 10 & 53 & 9 & - & - & - & - & - & 420 & - & 27 \\
\hline $10 \mathrm{Co} / 0 \mathrm{Ca}$ & 10 & 50 & - & - & - & - & - & 10 & 495 & - & - \\
\hline Na-free (Tris) & 10 & 50 & 10 & 375 & - & - & 100 & - & - & 5 & - \\
\hline Na-free (TMA) & 10 & 50 & 10 & - & 495 & 10 & - & - & - & - & - \\
\hline $0 \mathrm{Na}$ & 10 & 50 & 10 & 495 & - & - & - & - & - & - & - \\
\hline
\end{tabular}

All solutions have $\mathrm{pH} 7.6$ (adjusted with $\mathrm{HCl}$ ); all concentrations are in mM. Single additions of rubidium (5), cesium (10), cobalt (10), nickel (10), or potassium (20) were added hyperosmotically to normal ASW. The $50 \% \mathrm{Na}^{+}$-containing medium was obtained by making a mixture $(50: 50)$ of $0 \mathrm{Na}$ medium and normal ASW. 
Figure 2. Voltage-clamp records show that currents evoked by a BCB discharge in an $\mathrm{LB} / \mathrm{LC}$ target neuron are apparently identical to those evoked by ELH. $I-V$ relations were recorded by applying slow depolarizing ramp command potentials every $2.5 \mathrm{~min}$ before and after electrical triggering of a $\mathrm{BCB}$ or application of ELH. In both $A_{i}$ and $B_{l}$, the baseline (solid line) is composed of 5 consecutive, superimposed $I-V$ relations to show baseline stability. $A_{l}$, After triggering of a $\mathrm{BCB}$ (see Materials and Methods), the membrane current changed slowly over the course of 20 $\mathrm{min}$. The dotted line represents the current 25 min after the BCB was triggered. $A_{2}$, The BCB-evoked current was calculated by subtraction of the $I-V$ curve generated after a $\mathrm{BCB}$ was triggered from an average of the baseline $I-V$ relations. Note the different scale in the evoked current plots. $B_{1}$, In a different preparation, $10 \mu \mathrm{L}$ ELH was applied to the abdominal commissure area with a polyethylene pipette (concentration in the pipette $100 \mu \mathrm{M}) . B_{2}$, The ELHevoked current was calculated as in $A_{2}$.
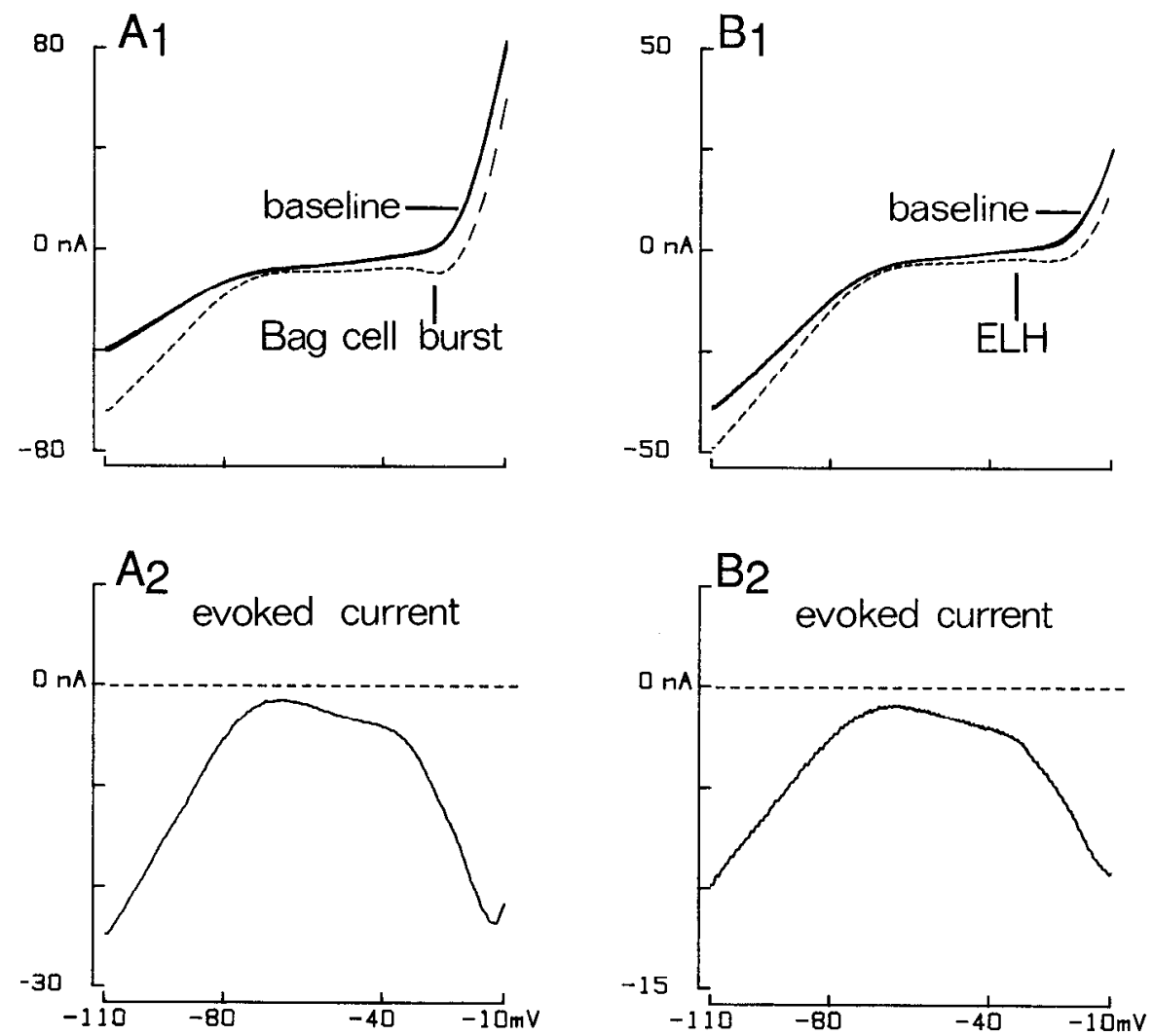

discharge in near unison for 20-30 min, releasing ELH and other peptides derived from the ELH/BCP precursor protein (see Mayeri et al., 1985). Such a bag cell burst, or applied ELH, produces long-lasting repetitive spiking in $\mathrm{LB}$ and $\mathrm{LC}$ neurons, which are normally silent or fire irregularly at low frequencies (Branton et al., 1978, Mayeri et al., 1979b). We found that BCBs and applied ELH induce persistent (apparently noninactivating) currents in these neurons, which develop over the course of 5$20 \mathrm{~min}$ and last for $30 \mathrm{~min}$ up to $2 \mathrm{hr}$.

It was important to verify that the baseline $I-V$ relations recorded before a $\mathrm{BCB}$ or application of ELH were stable, so that even small changes in long-lasting current induced by a BCB or application of ELH could be detected. Each preparation was therefore given ample time (typically $1-2 \mathrm{hr}$ ) to stabilize before the baseline data were taken. To measure the long-lasting currents, $I-V$ relations were generated using a depolarizing ramp command voltage. This ramp command voltage was applied every $2.5 \mathrm{~min}$ before and after application of ELH or stimulation of a BCB (Fig. 1). The baseline stability typically obtained is shown in Figure $2, A_{l}, B_{l}$, in which 5 successive baseline $I-V$ relations are superimposed. These baseline $I-V$ relations, obtained immediately before application of peptide or triggering of a BCB, were averaged. The net current evoked by the peptide or bag cell activity was then calculated by subtraction of the averaged baseline $I-V$ relation from $I-V$ relations generated after application of peptide or after bag cell activity.

The net currents evoked by BCBs $(n=6)$ or ELH $(n=6)$ were inward in 10 of 12 experiments over the entire voltage range tested (Fig. 2, $A, B$ ). In the other 2 experiments (one $\mathrm{BCB}$, one ELH-application), a small ( $<0.5 \mathrm{nA}$ ) outward current could be observed between about -75 and $-55 \mathrm{mV}$ (data not shown).
The currents evoked by BCBs and ELH were apparently identical in their voltage dependence. This provides additional evidence that ELH is a neurotransmitter in the abdominal ganglion.

The ELH-evoked current was found to be composed of three separable slow currents. The inflections in the evoked current curve at -70 and $-40 \mathrm{mV}$ (Fig. $2, A_{2}$ and $B_{2}$ ) indicated that the evoked current has at least 2 components with a steep voltage dependence. One component activates at membrane potentials below $-70 \mathrm{mV}$ and has an apparently lincar voltage dependence; it was subsequently identified as an inwardly rectifying potassium current, and termed $I_{\mathrm{R}}$. A second component activates at membrane potentials higher than about $-40 \mathrm{mV}$, and was termed $I_{\mathrm{SI}}$ (for slow inward). Additionally, we isolated a third, voltage-independent inward current, termed $I_{\mathrm{x}}$. As will be shown below, all 3 currents are slowly or noninactivating; they appear to sum algebraically to produce the ELH-evoked current shown in Figure 2.

\section{Currents evoked by ELH are slowly or noninactivating}

The ramp command voltage used provides no information about the activation and inactivation kinetics of the ELH-modulated currents. In particular, transient currents are likely to be inactivating continuously during the ramp and will therefore not contribute significantly to the ramp-generated membrane current. The time dependence of the ELH-cvokcd currents was therefore investigated with conventional square-wave command voltage steps of $250 \mathrm{msec}$ duration between -110 and $-10 \mathrm{mV}$ (Fig. 3, $n=3$ ). Figure $3 A$ shows the currents before and after application of ELH. The net ELH-evoked currents shown in Figure $3 B$ were calculated by subtraction. As with the ramp command potential, the ELH-evoked current was inward 
over the entire voltage range tested and caused a small inward shift of the holding current, which is apparent in the evoked current of Figure $3 B$ at the far left of each trace.

The currents evoked by ELH at membrane potentials below $-50 \mathrm{mV}$ activated rapidly and showed no sign of inactivation during the $250 \mathrm{msec}$ pulse. The currents evoked at -30 and $-10 \mathrm{mV}$, however, activated slowly, in about $75 \mathrm{msec}$, and showed no inactivation for the duration of the pulse. With pulses $>0 \mathrm{mV}$ and $>250 \mathrm{msec}$ (data not shown), slow inactivation of the ELH-evoked current could be seen. This inactivation process had a time constant of about $250 \mathrm{msec}$. Currents above $-10 \mathrm{mV}$ were not, however, analyzed further in this study. These data indicate that the 2 voltage-dependent currents (activated below $-70 \mathrm{mV}$ and above $-40 \mathrm{mV}$, respectively) have different activation kinctics.

To compare currents generated with square-wave pulses with those generated with the ramp command potential used in most of the experiments, a series of ramps and a series of squarewave command pulses were applied alternately before and after an ELH application. The currents measured at the end of each $250 \mathrm{msec}$ pulse were plotted together with the evoked current measured with the ramp command potential in Figure $3 C$. The currents obtained by the two methods compare well over the entire voltage range, indicating that using the ramp command voltage is an accurate way of measuring the slowly inactivating ELH-evoked currents.

\section{Nickel or cobalt ions block the 2 voltage-dependent currents evoked by ELH and reveal a third, steady inward current}

The data in Figures 2 and 3 are consistent with the idea that the ELH-evoked current is composed of at least 2 voltage-gated currents. The following experiments illustrated that there is a third ELH-evoked current, separate from $I_{\mathrm{R}}$ and $I_{\mathrm{sI}}$. To investigate the ionic mechanism of the response to applied ELH, we tried blocking ELH-evoked currents with $\mathrm{Ca}^{2+}$-channel blocking agents. Adding $10 \mathrm{mM} \mathrm{Ni}^{2+}$ or $10 \mathrm{mM} \mathrm{Co}^{2+}$ to the ASW bathing medium for 15-30 min dramatically changed the normal $I-V$ relation observed before the peptide is applied (Fig. $4 A_{1}$, dashed line). The outward current was greatly reduced, most likely as a result of indirectly blocking the $\mathrm{Ca}^{2+}$-dependent $\mathrm{K}^{+}$-current. In addition, a region with negative slope conductance appeared in the $I-V$ relations of some, but not all, cells.

With $\mathrm{Co}^{2+}\left(\right.$ or $\mathrm{Ni}^{2+}$ ) present in the bathing medium (Fig. 4A), the voltage-dependent components of the ELH-evoked current seen in normal ASW were substantially reduced. However, they were not blocked completely. There was also a residual evoked current that resulted in a downward shift of the entire $I-V$ relation (Fig. 4A, ). This downward shift was also observed in experiments in which ganglia were washed for long periods of time ( $>1 \mathrm{hr}$ ) with a medium in which all the $\mathrm{Ca}^{2+}$ was replaced with $\mathrm{Ni}^{2+}$ or $\mathrm{Co}^{2+}$ (Fig. 4B). The voltage-dependent currents were blocked completely by this procedure; the only response that remained was a small inward current whose conductance was independent of membrane voltage. The amplitude of this current, termed $I_{\mathrm{x}}$, was $2.2 \pm 0.7 \mathrm{nA}$ (SEM) measured at -80 $\mathrm{mV}(n=5)$. As in Figure $4 B_{2}$, the $I-V$ relation of $I_{\mathrm{X}}$ usually had a small, positive slope. Although the variability was such that the extrapolated reversal potential of this current could not be estimated accurately from these data, it is likely to be higher than $0 \mathrm{mV}$. The data thus indicate that the 2 voltage-dependent components of the ELH-evoked current are sensitive to $\mathrm{Ni}^{2+}$ and $\mathrm{Co}^{2+}$, albeit when applied for a prolonged period of time,
A

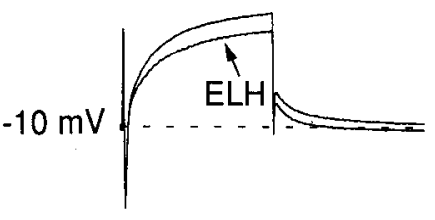

evoked current

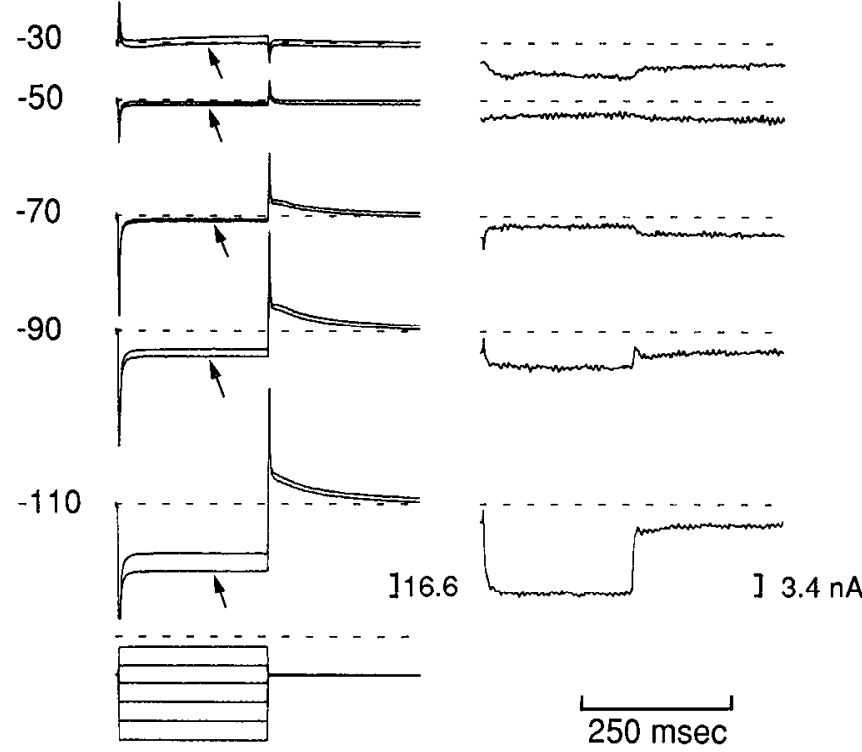

C

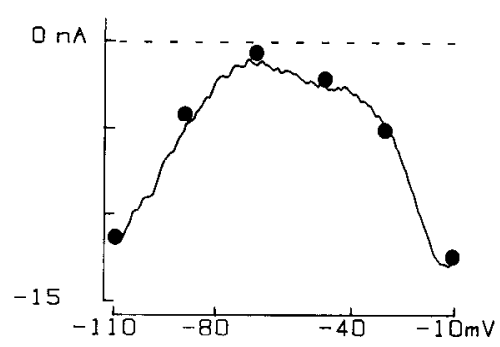

Figure 3. Currents investigated with square-wave voltage steps show the activation and inactivation characteristics of the ELH-evoked currents. $A$, The membrane potential was stepped from a holding potential of $-40 \mathrm{mV}$ to the indicated membrane potentials for $250 \mathrm{msec}$. The arrows indicate the current record after application of ELH. Zero current is indicated by the dashed line in each set of traces. The superimposed traces at the bottom show the command voltages. $B$, The ELH-evoked currents were calculated by subtraction of the records in $A$ (note the different vertical scale). The currents evoked at -10 and $-30 \mathrm{mV}$ were activated in about $75 \mathrm{msec}$. At membrane potentials below $-50 \mathrm{mV}$, the evoked currents activated rapidly. $C$, Comparison of square-wave and ramp-generated currents. The ELH-evoked currents, measured at the end of each square-wave step, were plotted together with ELHevoked current measured with the ramp command potential in the same cell, during the same ELH application data from the same preparation as $A$ and $B$. This shows that using the ramp command potential is an accurate way of measuring slow ELH-evoked currents.

and that $I_{\mathrm{x}}$ is an additional current, separate from the other components.

$\mathrm{I}_{S I}$ is a slow inward current separate from $\mathrm{I}_{R}$ and $\mathrm{I}_{X}$ and does not depend on the external $\mathrm{Na}^{+}$concentration

We next attempted to isolate the current evoked at membrane potentials above $-40 \mathrm{mV}$ from the other 2 postulated currents. 
Figure 4. Isolation of a steady, inward ELH-evoked current, $I_{\mathrm{x}}$, by application of calcium channel blocking agent $\mathrm{CO}^{2+}$ to the bathing medium. $A$, The normal baseline $I-V$ relation (dotted line) was changed dramatically when $10 \mathrm{mM} \mathrm{Co}^{2+}$ was added to normal seawater (upper solid line). The outward current at more depolarized membrane potentials is reduced, most likely by blocking the $\mathrm{Ca}^{2+}$ dependent $\mathrm{K}^{+}$current. Additionally, the inwardly rectifying current, seen below $-70 \mathrm{mV}$, was blocked. After ELH was applied (lower solid line), the $I-V$ relation shifted downward. $A_{2}$, The ELHevoked current was reduced in size compared with normal ELH responses but was not blocked completely. $B_{1}, I_{\mathrm{x}}$ could be isolated completely by washing the ganglion for extended periods of time with a medium in which all the $\mathrm{Ca}^{2+}$ was replaced with $\mathrm{Co}^{2+}$. The dashed line indicates the $I-V$ relation after application of ELII. $B_{2}$, The voltage-dependent currents that ELH normally evokes were blocked completely, and the only current that remained was a small inward current, $I_{x}$, with an apparently voltage-independent conductance.
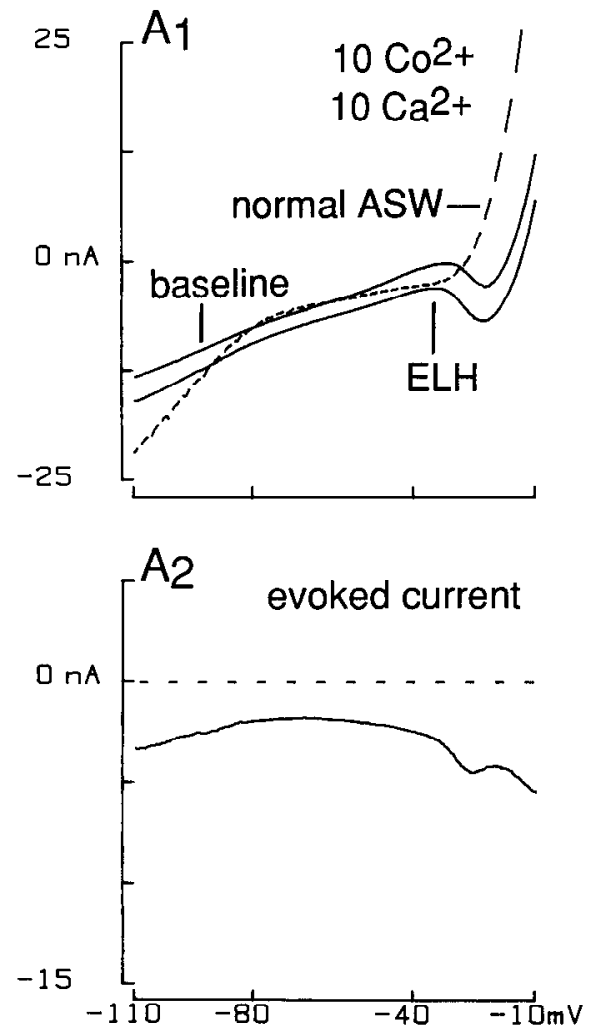
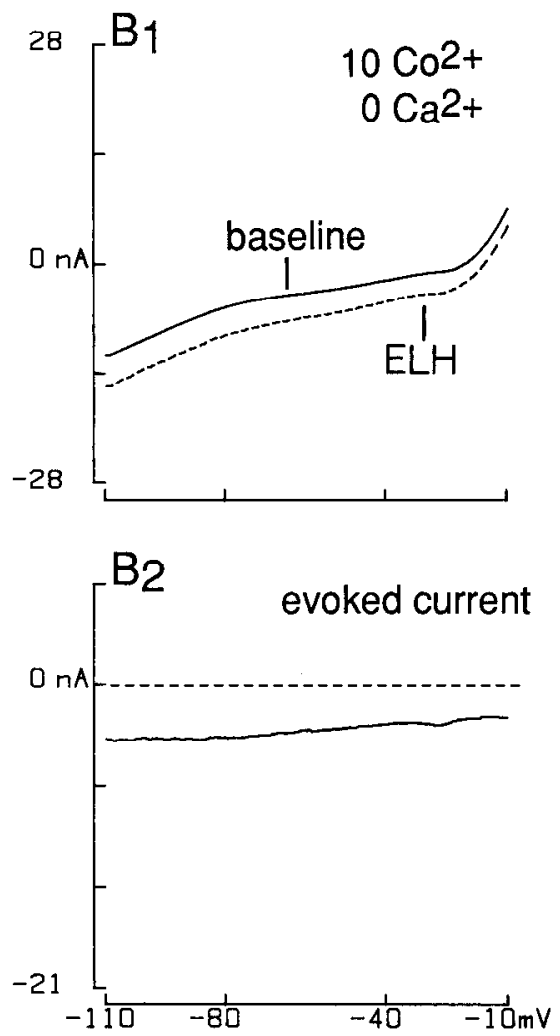

It is possible that this current is caused by a true inward current carried by $\mathrm{Ca}^{2+}$ and/or $\mathrm{Na}^{+}$, by a decreased outward current, or a combination of these. Since $I_{\mathrm{SI}}$ appears to be at least Ca sensitive (Fig. 4), we raised the external $\mathrm{Ca}^{2+}$ concentration from 10 to $30 \mathrm{~mm}$. In addition, $\mathrm{Na}^{+}$currents were eliminated by replacing all external $\mathrm{Na}^{+}$with Tris, $5 \mathrm{~mm} \mathrm{Rb}^{+}$was added to block the inwardly rectifying $\mathrm{K}^{+}$current, and $100 \mathrm{~mm} \mathrm{TEA}^{+}$ was added to block the delayed rectifier and the $\mathrm{Ca}^{2+}$-dependent $\mathrm{K}^{+}$currents (Hermann and Gorman, 1981; $n=4$ ).

Figure $5 A_{2}$ shows that these ion substitutions blocked the
Figure 5. Isolation of a slow inward current, $I_{\mathrm{Sl}}$, by agents that block $\mathrm{Na}^{+}$ and $\mathrm{K}^{+}$currents. $A_{l}$, The ganglion was bathed in a medium containing $5 \mathrm{~mm}$ $\mathrm{Rb}^{\prime}, 100$ mm TEA', and 375 mm Tris to block the inwardly rectifying $\mathrm{K}^{+}$current, the delayed rectifying, and the $\mathrm{Ca}^{2+}$-dependent $\mathrm{K}^{+}$currents and all $\mathrm{Na}^{+}$ currents, respectively. Additionally, the $\mathrm{Ca}^{2+}$ concentration was raised to $30 \mathrm{~mm}$. The baseline $I-V$ relation (solid line) shows the absence of any inward rectification. The dashed line represents the $I-V$ relation after application of ELH. $A_{2}$, The current that ELH evokes in this medium was termed $I_{\mathrm{SI}}$, a current separate from $I_{\mathrm{X}}$ and $I_{\mathrm{R}} . B_{l}$, In a different preparation, the ganglion was bathed in a medium in which all external $\mathrm{Na}^{\prime}$ was replaced with $\mathrm{TMA}^{+}$. $B_{2}$, Application of ELH showed that both $I_{\mathrm{x}}$ and $I_{\mathrm{R}}$ were blocked but that $I_{\mathrm{SI}}$ was apparently unaffected.
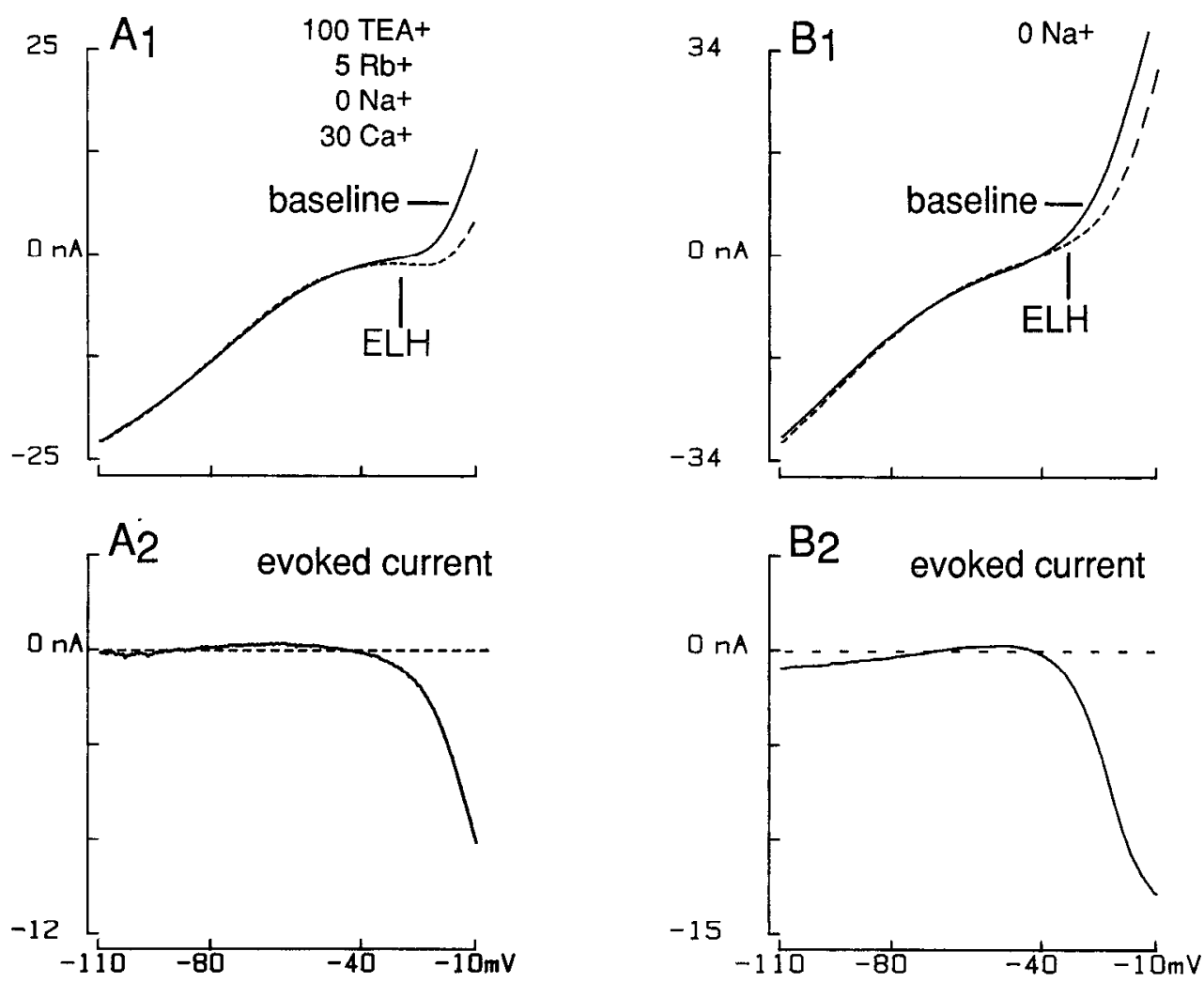
ELH-evoked current below about $-70 \mathrm{mV}$ and the inward current $I_{\mathrm{x}}$. The voltage-dependent current that is evoked above $-40 \mathrm{mV}$ was still present, however, and appeared to be of about the same magnitude in this voltage range as the current evoked in normal seawater (Figs. 2, 3). This indicates that $I_{\mathrm{SI}}$ is a separate current and that it is not likely to be a $\mathrm{Na}$ ' current. Although $I_{\mathrm{SI}}$ is $\mathrm{Ca}^{+2}$-sensitive, its dependence on $\mathrm{Ca}^{2+}$ or other ions as a charge carrier remains to be determined. Replacing $\mathrm{Na}^{+}$ with $\mathrm{TMA}^{+}$in otherwise normal ASW did not appear to affect $I_{\mathrm{SI}}$ either, but it did block $I_{\mathrm{R}}$ and $I_{\mathrm{X}}$ (Fig. $5 B, n=2$ ). Possibly, the blocking of the latter 2 currents was due to nonspecific effects of the high (495 mM) TMA ${ }^{+}$concentration.

\section{$\mathrm{I}_{R}$ is an inwardly rectifying $\mathrm{K}^{+}$current}

The current remaining after subtracting $I_{\mathrm{SI}}$ (Fig. $5 A_{2}$ ) and $I_{\mathrm{x}}$ (Fig. $4 B_{2}$ ) from the total evoked current shown in Figure 2 has an inwardly rectifying $I-V$ relation with a reversal potential that is close to the reversal potential of $\mathrm{K}^{+}$. Three criteria have been used to identify inwardly rectifying $\mathrm{K}^{+}$currents: (1) It is activated when the membrane is hyperpolarized to potentials that are near or below $E_{\mathrm{K}},(2)$ its chord conductance depends on the external $\mathrm{K}$ concentration, and (3) the current is blocked by externally added rubidium and cesium (Hagiwara and Takahashi, 1974; Hagiwara and Yoshii, 1979; Stanfield et al., 1985).

We used these criteria to determine if the ELH-evoked current that is activated below approximately $-70 \mathrm{mV}$ is an inwardly rectifying $\mathrm{K}^{+}$current. To determine if it is a $\mathrm{K}^{+}$current, we increased the potassium concentration outside the cell $\left(\left[\mathrm{K}^{+}\right]_{0}\right)$ from 10 (normal ASW) to $30 \mathrm{mM}$ and applied ELH (Fig. $6 a ; n$ $=3$ ). The membrane potential at which $I_{\mathrm{R}}$ activates in the basclinc $I$ - $V$ rclation (Fig. $6 A$, solid lines) was shifted from about $-70 \mathrm{mV}$ in $10 \mathrm{mM} \mathrm{K}^{+}$to $-45 \mathrm{mV}$ in $30 \mathrm{mM} \mathrm{K}^{+}$. In addition, the extrapolated reversal potential of the ELH-evoked current shifted from about $-70 \mathrm{mV}$ in $10 \mathrm{~mm} \mathrm{~K} \mathrm{~K}^{+}$(Fig. 2), to about $-50 \mathrm{mV}$ in $30 \mathrm{~mm} \mathrm{~K}^{+}$(Fig. $6 \mathrm{~A}_{2}$ ). The change in extrapolated reversal potential compares well with the shift predicted from the Nernst potential for potassium, from -76 to $-48 \mathrm{mV}$. In addition, in low external $\mathrm{K}^{\prime}(1 \mathrm{~mm})$, the activation of inward rectification was shifted to lower membrane potentials, consistent with the idea that $I_{\mathrm{R}}$ is a $\mathrm{K}^{+}$current (data not shown).

Associated with the change of $\left[K^{+}\right]_{0}$ from 10 to $30 \mathrm{~mm}$, there was a dramatic change in the slope of the $I-V$ relation below $E_{\mathrm{K}}$, the reversal potential for $K^{+}\left(E_{\mathrm{K}}\right.$ is indicated by the arrows in Fig. 6). At both the whole-cell and the single-channel level (Hagiwara and Takahashi, 1974; Fukushima, 1982) it has been shown that the conductance of the inwardly rectifying $\mathrm{K}^{+}$current is roughly proportional to $\left(\left[\mathrm{K}^{+}\right]_{0}\right)^{-1 / 2}$. This is in contrast with the linear dependence on $\left[\mathrm{K}^{+}\right]_{\text {o }}$, predicted by the constant-field assumption (see Hagiwara and Takahashi, 1974). Accordingly, we found that the slope of the $I-V$ relation below $E_{\mathrm{K}}$ in Figure 6 $A_{2}$ increased 1.7-fold upon changing $\left[\mathrm{K}^{+}\right]_{\mathrm{o}}$ from 10 to $30 \mathrm{~mm}$, exactly as predicted from the square-root relation for a 3 -fold increase in $\left[\mathrm{K}^{+}\right]_{0}$.

\section{Chord conductance of $\mathbf{I}_{R}$ depends on the external $K^{+}$ concentration}

Inwardly rectifying $\mathrm{K}^{+}$channels are unique in that the gating of the channel depends not only on the membrane potential, but on the external potassium concentration as well (Hagiwara and Takahashi, 1974). It was not possible for us to isolate $I_{\mathrm{R}}$ pharmacologically from the other ELH-evoked currents. We therefore used substraction methods to isolate $I_{\mathrm{R}}$ to investigate this
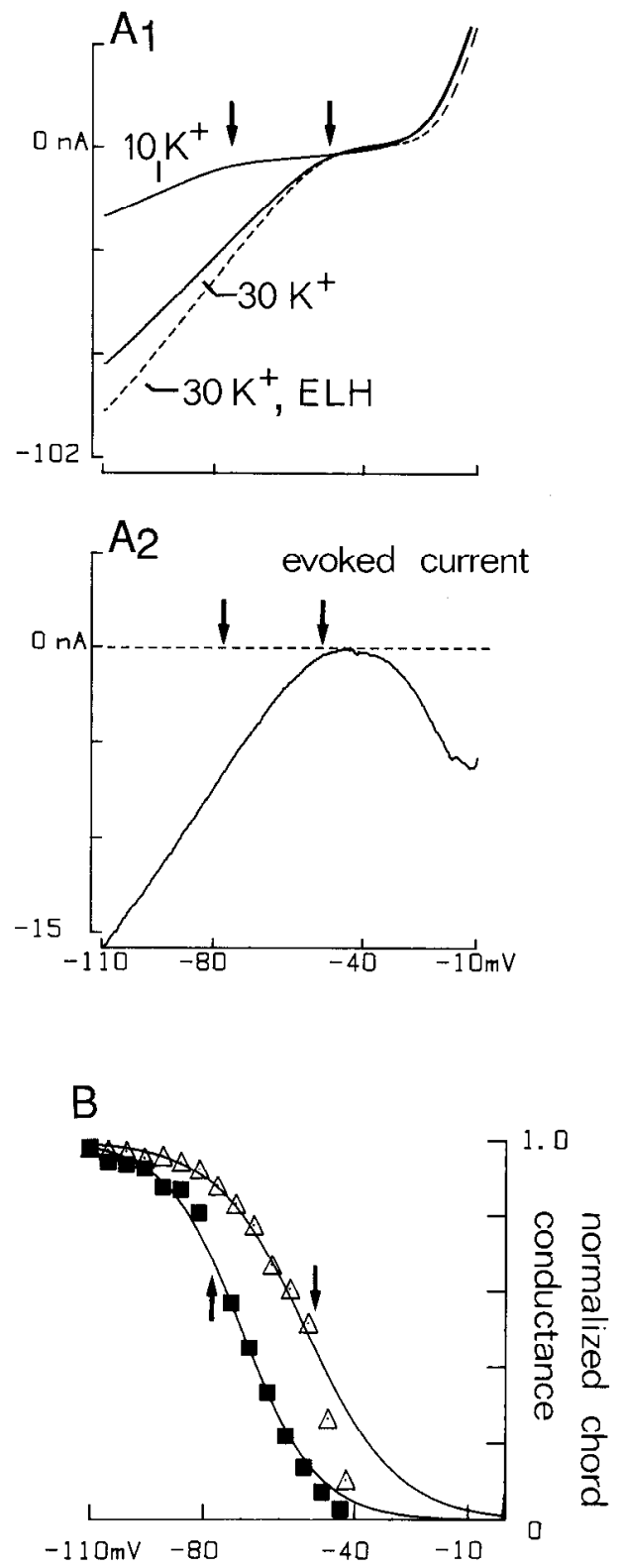

Figure 6. ELH modulates an inwardly rectifying $\mathrm{K}^{+}$current. $A_{l}$, In normal $\left(10 \mathrm{~mm} \mathrm{~K} \mathrm{~K}^{+}\right)$seawater, the inwardly rectifying current activates below about $-70 \mathrm{mV}$. When the external $\mathrm{K}^{+}$concentration is raised to $30 \mathrm{~mm}$, the theoretical reversal potential for $\mathrm{K}^{+}\left(E_{\mathrm{K}}\right)$, shifts from -76 to $-48 \mathrm{mV}$ (indicated by the arrows). The slope of the $I-V$ relation below $E_{\mathrm{K}}$ increases about 1.7-fold, with a 3-fold change in $\left[\mathrm{K}^{+}\right]_{\text {o }}$, whereas at membrane potentials above $-48 \mathrm{mV}$, the $I-V$ relation shows very little change (solid lines). The dashed line indicates the $I-V$ relation in $30 \mathrm{mM} \mathrm{K}{ }^{+}$after application of ELH. $A_{2}$, The membrane potential at which the ELH-evoked $I_{\mathrm{R}}$ activates shifted with $E_{\mathrm{K}}$, from about -70 $\mathrm{mV}$ (compare Fig. 2) to about $-50 \mathrm{mV}$. $B$, To isolate $I_{\mathrm{R}}$, a voltageindependent current with the characteristics of $I_{\mathrm{x}}$ was subtracted to make the current at the theoretical $E_{\mathrm{K}}$ zero. The chord conductance of the ELH-evoked current was then calculated by dividing the current by the driving force on $\mathrm{K}^{+}, V-E_{\mathrm{K}}$. Plotting the normalized chord conductance measured in $10 \mathrm{mM} \mathrm{K} \mathrm{K}^{+}$(solid squares) and $30 \mathrm{mM} \mathrm{K}^{+}$(open triangles) against the membrane potential indicates that the chord conductance shifts with the external potassium concentration, a unique property of the inwardly rectifying $\mathrm{K}^{+}$current. The normalized chord conductances in 10 and $30 \mathrm{~mm} \mathrm{~K}^{+}$were fitted with Boltzmann equations (solid lines). The parameters used are explained in the text. The arrows indicate $E_{\mathrm{K}}$ in 10 and $30 \mathrm{mM} \mathrm{K} \mathrm{K}^{+}$, respectively. 
Figure 7. The ELH-evoked $I_{\mathrm{R}}$ is blocked by external $\mathrm{Cs}^{+}$. $A_{l}$, When 10 $\mathrm{mM} \mathrm{Cs}^{+}$is added to normal seawater, the inward rectification, normally present in these cells (solid line), is blocked (dashed line). $A_{2}$, The cesium-sensitive current shows that the blocked current indeed is inwardly rectifying and has a reversal potential of about $-86 \mathrm{mV} . B_{l}$, When ELH is later applied to the same ganglion bathed in $10 \mathrm{~mm}$ ccsium-containing seawater, ELH no longer evokes the voltage-dependent current below about $-70 \mathrm{mV}$ that is seen in normal ASW (solid line, baseline; dotted line, ELH). $B_{2}$, With cesium present, the ELH-evoked current only shows an $I_{\mathrm{s} 1}$, whereas $I_{\mathrm{X}}$ and $I_{\mathrm{R}}$ are apparently blocked.
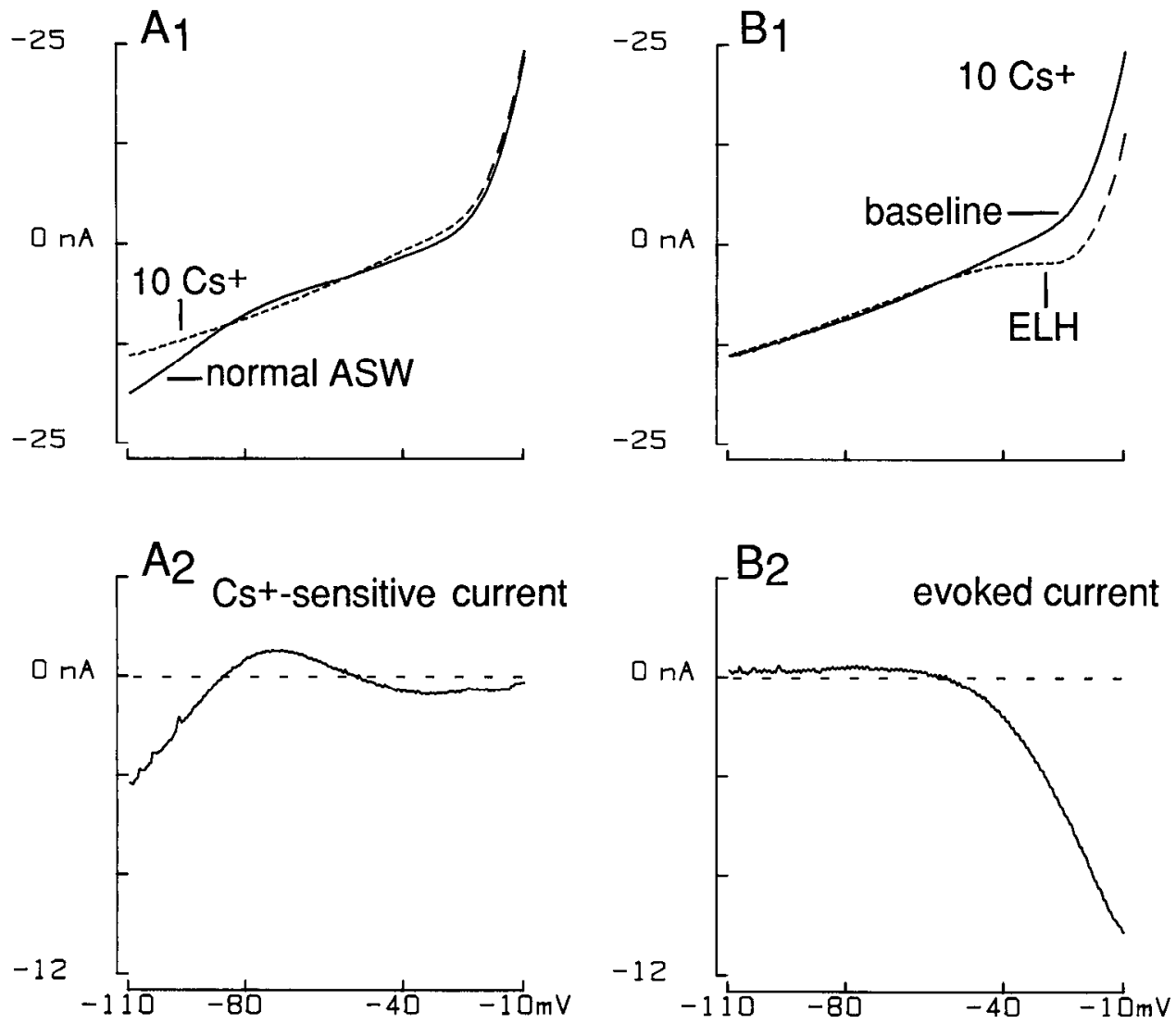

feature. At membrane potentials below $-50 \mathrm{mV}$, we postulated that 2 ELH-evoked inward currents are active: $I_{\mathrm{R}}$ and $I_{\mathrm{x}}$ (see Figs. 4 and 6). To isolate the $\mathrm{K}^{+}$-sensitive current, a theoretical voltage-insensitive current similar to $I_{\mathrm{x}}$ was substracted from the ELH-evoked current. The value of $I_{\mathrm{x}}$ was set so as to make the net evoked current zero at the theoretical $E_{\mathrm{K}}$. The values used for $E_{\mathrm{K}}$ in normal and high $\mathrm{K}^{+}$-containing seawater were -77.3 and $-51.9 \mathrm{mV}$, respectively. These values are close to the values of $E_{\mathrm{K}}$ in normal ASW ( $-76 \mathrm{mV}$, measured directly in Aplysia neurons; Kunze and Brown, 1971) and $30 \mathrm{~mm} \mathrm{\textrm {K } ^ { + }}$ $(-48 \mathrm{mV})$ and were used in the Boltzmann fit, described below. The chord conductance at each membrane potential, $V$, was then obtained by dividing the current by driving force on $\mathrm{K}^{+}$ $\left(V-E_{\mathrm{K}}\right)$. Plotting the chord conductance of $I_{\mathrm{R}}$, isolated in this way, in normal (Fig. $6 B$, solid squares) and $30 \mathrm{mM} \mathrm{K}^{+}$ASW (Fig. 6B, open triangles) against the membrane potential, indicates that there is a sigmoidal decrease in the chord conductance at membrane potentials near and above $E_{\mathrm{K}}$. This sigmoidal chord conductance shifted with the external $\mathrm{K}^{+}$ concentration. The shift is a unique property of inwardly rectifying potassium currents (data from Figs. $2 B_{2}$ and $6 A_{2}$ ).

Hagiwara and Takahashi (1974) found that the chord conductance of the inwardly rectifying $\mathrm{K}^{+}$current in starfish egg could be described by Boltzmann expressions of the form

$$
g_{k}=g_{k}^{\prime}\left\{1+\exp \left[V-V^{\prime} / k\right]\right\}^{-1}
$$

where $g_{k}=$ potassium conductance; $g_{k}^{\prime}=$ limiting potassium conductance, $V=$ membrane potential, and $V^{\prime}=$ membrane potential at half-maximal $g_{{ }^{\prime}}$. The parameter $k$ determines the shape (steepness) of the curve. Correspondingly, we found that the ELH-evoked currents in 10 and $30 \mathrm{~mm}$, isolated with the subtraction method, could be fitted by this expression (Fig. $6 C$, solid lines) using the following parameters: normal $\mathrm{K}^{+:} V^{\prime}=$ $-70 \mathrm{mV}, k=10 \mathrm{mV}, E_{\mathrm{K}}=-77.3 \mathrm{mV}$; high $\mathrm{K}^{+}: V^{\prime}=-53$ $\mathrm{mV}, k=12 \mathrm{mV}, E_{\mathrm{K}}=-51.9 \mathrm{mV}$. The data were fit by eye. The subtraction procedure used separates $I_{\mathrm{R}}$ from $I_{\mathrm{X}}$ but not from $I_{\mathrm{SI}}$, which activates at more depolarized membrane potentials. Activation of $I_{\mathrm{SI}}$ therefore potentially interferes with the curve fitting, and presumably caused the data points at membrane potentials less negative than $-50 \mathrm{mV}$ to deviate from the Boltzmann fit.

\section{$\mathrm{I}_{R}$ is blocked by external rubidium and cesium ions}

Cesium and rubidium have been used to block inwardly rectifying $\mathrm{K}^{+}$currents (IIagiwara and Takahashi, 1974; Gay and Stanfield, 1977; Benson and Levitan, 1983). When added to normal seawater, $\mathrm{Rb}^{+}(5 \mathrm{mM})$ or $\mathrm{Cs}^{+}(10 \mathrm{mM})$ blocked an inwardly rectifying current that is normally present in $\mathrm{LB}$ and $\mathrm{LC}$ neurons in the absence of the peptide (Fig. $7 A$; total $n=7$ ). This current (Fig. $7 A_{2}$ ) had an average reversal potential of $-86 \mathrm{mV}$ ( $\pm 2.9 \mathrm{mV}$ SEM). With the $\mathrm{Cs}^{+}$-sensitive current blocked, the ELH-evoked current showed no inward current below $-70 \mathrm{mV}$ (Fig. $7 B$ ), whereas the inward current evoked above $-40 \mathrm{mV}$ did not seem to be reduced compared with responses to ELH in normal seawater (Fig. $2 B$ ). This indicates that $\mathrm{Cs}^{+}$and $\mathrm{Rb}^{+}$ block the inwardly rectifying $\mathrm{K}^{+}$current that is normally enhanced by ELH.

Additionally, $\mathrm{Cs}^{+}$and $\mathrm{Rb}^{+}$also appear to block the postulated current $I_{\mathrm{x}}$ : The ELH-evoked current does not show any inward current below $-50 \mathrm{mV}$. In support of this interpretation, the $\mathrm{Rb}^{+}$- or $\mathrm{Cs}^{+}$-sensitive current has an average reversal potential that is about $10 \mathrm{mV}$ more negative than expected from the 
$\min$.
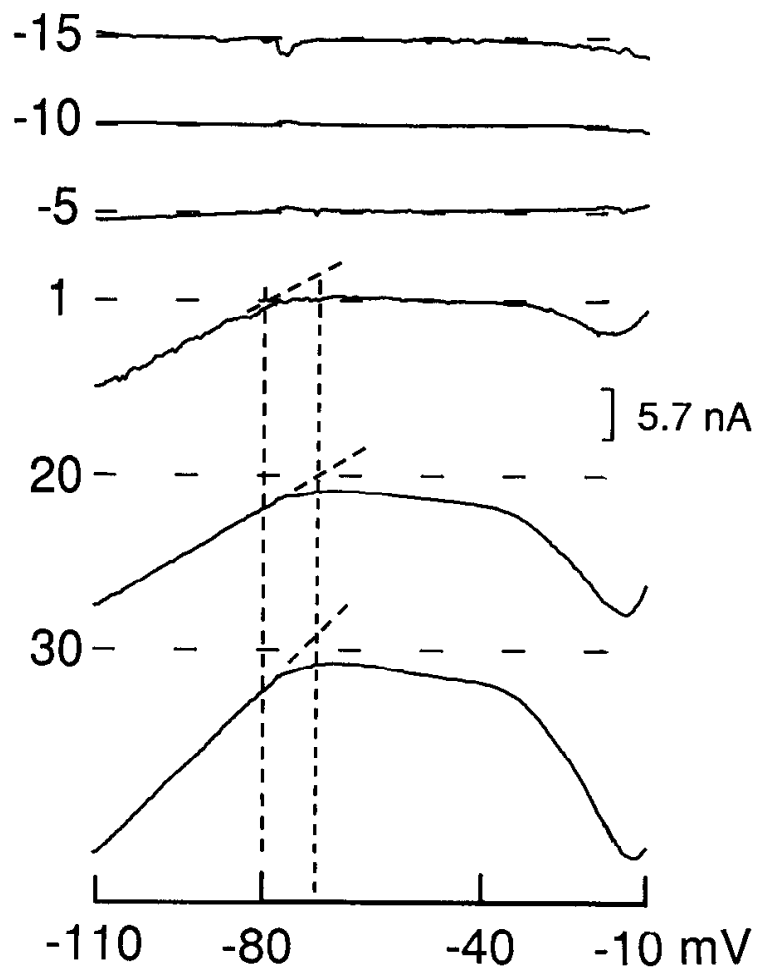

Figure 8. Differential development of BCB-evoked currents also suggests the existence of $I_{\mathrm{x}}$. Using data from the same preparation as in Figure $2 A$, the baseline $I-V$ relations were averaged, and the difference between the individual baseline records and the average was calculated to demonstrate baseline stability. Three of those records, marked 15 , -10 , and $-5 \mathrm{~min}$, are shown. At $t=0$, a $\mathrm{BCB}$ was triggered, and the development of the different components of the ELH-evoked current was followed by plotting successive evoked current relations. After 1 min, only $I_{\mathrm{R}}$ and $I_{\mathrm{S}}$ were visible. $I_{\mathrm{R}}$ had a reversal potential (calculated by extrapolation of the linear part of the evoked current below -80 $\mathrm{mV}$ ) of $-80 \mathrm{mV}$, and there was no current evoked between about -80 and $-40 \mathrm{mV}$. After $20 \mathrm{~min}$, the FLH-evoked current was inward at all membrane potentials, and $I_{\mathrm{R}}$ now had an extrapolated reversal potential of about $-70 \mathrm{mV}$. After $30 \mathrm{~min}$, the ELH-evoked current was fully developed in this example.

Nernst potential for $\mathrm{K}^{+},-86$ rather than $-76 \mathrm{mV}$. This is as cxpected if $\mathrm{Cs}^{+}$and $\mathrm{Rb}^{+}$were to block $I_{\mathrm{x}}$, since it would shift the $I-V$ relation of the $\mathrm{Cs}^{+}$-sensitive current upward and the reversal potential to more negative values.

Differential development of $B C B$ - or ELH-evoked currents also suggests the existence of $\mathrm{I}_{X}$.

In most preparations, the total BCB- or ELH-evoked current was fully developed in 5-30 min after triggering a BCB or applying ELH. Figure 8 shows a typical example of the development of BCB-evoked current in normal seawater (data from Fig. $2 A$ ). Baseline $I-V$ relations were averaged, and baseline stability was demonstrated by calculating the differences between the baseline average and each of the individual baseline $I-V$ relations. Three such evoked current relations are plotted in Figure 8 for baseline relations recorded at 15, 10, and $5 \mathrm{~min}$ before the $\mathrm{BCB}$, showing that the baseline was stable. At 0 min, a BCB was triggcred and the development of the evoked current was followed for $30 \mathrm{~min}$.
A
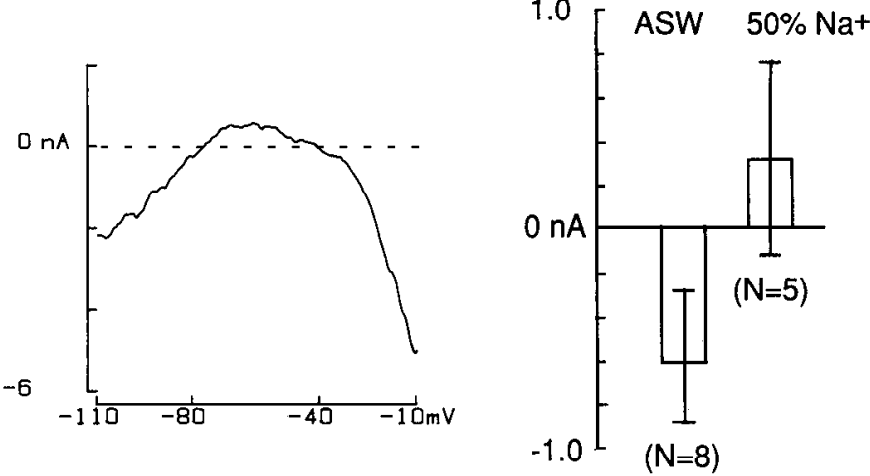

Figure 9. Reducing external $\mathrm{Na}^{+}$to $50 \%$ abolished the ELH-evoked downward shift of the $I-V$ relation. $A$, The ganglion was bathed in a medium in which $50 \%$ of the external $\mathrm{Na}^{+}$was replaced with Tris, and ELH was applied. In contrast with the ELH-evoked current in normal seawater (see Fig. $2 B$ ), the ELH-evoked current in $50 \% \mathrm{Na}^{+}$showed a reversal potential close to $-76 \mathrm{mV}$, the reversal potential for $\mathrm{K}^{+}$. The evoked current was outward between about -75 and $-55 \mathrm{mV}$. $B$, Comparison of the ELH-evoked currents seen in normal and in $50 \% \mathrm{Na}^{+}-$ containing seawater, measured close to $E_{\mathrm{K}}$. In normal seawater, the average current at $-72.5 \mathrm{mV}$ was inward: $-0.6 \mathrm{nA}( \pm 0.3 \mathrm{nA} \mathrm{SEM} ; N$ $=8$ ); in $50 \% \mathrm{Na}^{+}$-containing seawater, the average current at -72.5 $\mathrm{mV}$ was outward: $+0.3 \mathrm{nA}( \pm 0.4 \mathrm{nA} \mathrm{SEM} ; n=5)$.

After 1 min, two distinct voltage-dependent currents were visible: $I_{\mathrm{R}}$, which was discernible at membrane potentials below $-80 \mathrm{mV}$, and $I_{\mathrm{SI}}$ at membrane potentials above $-40 \mathrm{mV}$. However, no evoked current was visible between -70 and $-40 \mathrm{mV}$. After 20 min both $I_{\mathrm{R}}$ and $I_{\mathrm{SI}}$ currents were increased in size (as judged by their respective slope conductances), and the evoked current was now inward over the entire voltage range. Interestingly, the reversal potential for $I_{\mathrm{R}}$, extrapolated from the straightline $I-V$ relation below $-80 \mathrm{mV}$, had shifted from its original value of $-80 \mathrm{mV}$ at $1 \mathrm{~min}$ to $-70 \mathrm{mV}$ at $20 \mathrm{~min}$. $\Lambda \mathrm{t} 30 \mathrm{~min}$ the current was fully developed, and when released from voltage clamp, the cell was found to be firing spontaneously. (In 5 experiments the extrapolated reversal potential measured at maximal response was $-68 \pm 3.8 \mathrm{mV}$ SEM). The shift in extrapolated reversal potential can be accounted for by a downward shift in the $I-V$ relation (see Fig. 4) due to the onset of $I_{\mathrm{x}}$. As $I_{\mathrm{x}}$ sums with $I_{\mathrm{R}}$, the extrapolated reversal potential is shifted from near the equilibrium potential for $\mathrm{K}^{+}$to more positive values.

An alternative explanation for the shift in the reversal potential is that it is caused by the accumulation of $\mathrm{K}^{+}$ions at the outside of the cell membrane. However, the ramp command starts at $-110 \mathrm{mV}$, below $E_{\mathrm{K}}$, and is preceded by a hyperpolarizing step that lasts for $10 \mathrm{sec}$. During this $10 \mathrm{sec}$ phase a considerable $\mathrm{K}^{+}$influx, not efflux, is expected due to the inward rectification of the $I-V$ relation. Therefore, extracellular $\mathrm{K}^{+}$accumulation does not seem to be a reasonable explanation for the relatively depolarized extrapolated reversal potential. The $I_{\mathrm{SI}}$ current activates only above $-40 \mathrm{mV}$ (Figs. 5, $A_{2}, B_{2} ; 7 B_{2}$ ) and it cannot account for the shift in the reversal potential of $I_{\mathrm{R}}$. We therefore conclude that $E_{\mathrm{K}}$ is the real reversal potential for $I_{\mathrm{R}}$ and that the shift of the extrapolated reversal potential to $-70 \mathrm{mV}$, visible in the 20 and $30 \mathrm{~min}$ traces, results from the development of $I_{\mathrm{x}}$. 
Low external $\mathrm{Na}^{+}$selectively blocks the downward shift of the $\mathrm{I}-\mathrm{V}$ relation

The idea that a part of the ELH-evoked current serves to shift the entire $I-V$ relation downward is borne out by another experimental approach that appears to selectively block $I_{\mathrm{x}}$. We applied ELH to ganglia that were bathed in a medium in which $50 \% \mathrm{Na}^{+}$was replaced with Tris. As opposed to the ELH-cvoked current in normal seawater (Fig. 2), the ELH-evoked current in $50 \% \mathrm{Na}^{+}$medium was outward rather than inward in the -80 to $-40 \mathrm{mV}$ range in 5 out of 6 experiments (Fig. $9 A$ ). Moreover, the average reversal potential was $-74.5 \mathrm{mV}( \pm 5.6 \mathrm{mV} \mathrm{SEM}$; $n=5$ ), close to the theoretical value of $-76 \mathrm{mV}$ for $E_{\mathrm{K}}$. This result indicates that the downward shift in the $I-V$ relation is produced by $I_{\mathrm{x}}$ and that it was abolished in $50 \% \mathrm{Na}$ '. Figure $9 B$ shows the size of the ELH-evoked current in normal and $50 \% \mathrm{Na}^{+}$seawater, measured close to $E_{\mathrm{K}}$. In normal seawater, the average current at $-72.5 \mathrm{mV}$ was inward: $-0.6 \mathrm{nA}( \pm 0.3$ $\mathrm{nA} \mathrm{SEM} ; n=8)$. In $50 \% \mathrm{Na}^{+}$, the average current at $-72.5 \mathrm{nV}$ was outward: $+0.3 \mathrm{nA}( \pm 0.4 \mathrm{nA}$ SEM; $n=5)$. These experiments thus suggest that $I_{\mathrm{X}}$ is a $\mathrm{Na}^{+}$-sensitive current that shifts the whole $I-V$ relation downward and causes a shift of the extrapolated potential for the $I-V$ relation extrapolated from below $-80 \mathrm{mV}$.

\section{Discussion}

The present study shows that the current evoked by the neuropeptide ELH comprises at least 3 different components $I_{\mathrm{SI}}$ (Figs. 5, 7), $I_{\mathrm{R}}$ (Fig. 6), and $I_{\mathrm{X}}$ (Fig. 4). Additionally, this study showed that BCBs and application of ELH evoke apparently identical currents in target neurons of the abdominal ganglion. Since each component of the ELH-evoked current was slowly inactivating or noninactivating, it was possible to analyze the currents using a ramp command potential. However, since the ramp selectively measures slow currents, it is possible that other, rapidly inactivating currents are also modulated by ELH. In particular, ELH modulates a transient potassium current in addition to the currents described here. Analysis of this current and of $I_{\mathrm{SI}}$ will be described in a subsequent paper (R. F. Jansen and E. Mayeri, unpublished observations).

Mayeri et al. (1985) showed that ELH still affects LB and LC neurons when fast synaptic transmission was blocked or when the cells were surgically isolated in a small cluster. In the present study, the cells were usually surgically isolated in a small cluster, but left within the ganglion. It therefore seems likely that all the effects of BCBs and ELH are direct. With few exceptions all of the currents modulated by ELH appeared to be modulated in each cell.

\section{Modulation of the slow inward current}

The ELH-evoked $I_{\mathrm{SI}}$ current was apparently unaffected by complete removal of external $\mathrm{Na}^{+}$in the presence of $100 \mathrm{mM} \mathrm{TEA}^{+}$, which is reported to block close to $90 \%$ of the delayed rectifier $\mathrm{K}^{+}$current and almost $100 \%$ of the $\mathrm{Ca}^{2+}$-dependent $\mathrm{K}^{+}$current in Aplysia neuron $\mathrm{R}_{15}$ (Hermann and Gorman, 1981). It thus appears that $I_{\mathrm{SI}}$ is not produced by an increase of a $\mathrm{Na}^{+}$current or by reduction of either of these $2 \mathrm{~K}^{+}$currents. However, there have been several reports of relatively TEA-resistant $\mathrm{K}^{+}$currents in Aplysia (Klein and Kandel, 1980; Deitmer and Eckert, 1985), and the present data do not exclude the possibility that a TEA ${ }^{+}-$ resistant $\mathrm{K}^{+}$current underlies $I_{\mathrm{SI}}$. Since $I_{\mathrm{SI}}$ was blocked by re- placing external $\mathrm{Ca}^{2+}$ with $\mathrm{Co}^{2+}$, we conclude that $I_{\mathrm{sl}}$ is a $\mathrm{Ca}^{2+}-$ sensitive current and that the charge carrier is not $\mathrm{Na}^{+}$.

In the buccal motorneuron $\mathrm{B}_{16}$ of $A$ plysia, applied ELH causes repetitive firing that is caused by a slow inward current. Contrary to the present results, however, this ELH-evoked current was blocked by removing external $\mathrm{Na}^{+}$and was not reduced by $\mathrm{Ca}^{2+}$ channel blocking agents (Kirk and Scheller, 1986). Furthermore, currents similar to $I_{\mathrm{R}}$ or $I_{\mathrm{x}}$ were not evoked by ELH in this neuron. It thus appears that ELH modulates different currents in different parts of the brain of Aplysia to induce repetitive firing.

\section{Modulation of an inwardly rectifying $K^{\prime}$ current}

The most complete analysis in this study was done for the ELHevoked current $I_{\mathrm{R}}$. This current appears to be a pure $\mathrm{K}$ ' current and has all the properties that have been described for inwardly rectifying $\mathrm{K}^{+}$currents. Both the sensitivity of the chord-conductance of $I_{\mathrm{R}}$ to $\left[\mathrm{K}^{+}\right]_{0}$ and the fact that the slope conductance of the $I-V$ curve changes proportionally with the square root of $\left[\mathrm{K}^{+}\right]_{\mathrm{o}}$ are unique properties of inwardly rectifying $\mathrm{K}^{+}$currents. Additionally, the experiments with the blocking agents $\mathrm{Cs}^{+}$and $\mathrm{Rb}^{+}$indicate that $I_{\mathrm{R}}$ is similar to the inwardly rectifying $\mathrm{K}^{+}$ current found in frog muscle and starfish egg (Adrian, 1969; Hagiwara and Takahashi, 1974).

Modulation by peptides of $\mathrm{K}^{+}$currents similar to $I_{\mathrm{R}}$ has been described in a number of preparations: $I_{\mathrm{R}}$ is increased by $5-\mathrm{HT}$ in the cell $R_{15}$, by alpha-bag cell peptide in the bag cells (Benson and Levitan, 1983; Kauer and Kaczmarek, 1986), and suppressed by substance $P$ in cultured magnocellular neurons (Stanfield et al., 1985) and by L-glutamate in Carassius auratus (goldfish) retinal horizontal cells (Kaneko and Tachibana, 1985). Unlike some of these examples, however (Benson and Levitan, 1983; Stanfield et al., 1985), in the present study both the inwardly rectifying current present in the baseline $I-V$ relation and the $I_{\mathrm{R}}$ evoked by ELH were shown to be substantially reduced by $\mathrm{Ca}^{2+}$ channel blocking agents like $\mathrm{Co}^{2+}$ and $\mathrm{Ni}^{2+}$. At present, we do not know the mechanism of this action. There are, however, reports to suggest that inwardly rectifying $\mathrm{K}^{+}$currents are sensitive to intracellular calcium (Kramer and Levitan, 1986) and magnesium levels (Matsuka et al., 1987; Vandenberg, 1987).

\section{Modulation of the steady inward current}

Several lines of evidence indicate that $I_{\mathrm{X}}$ is a third ELH-evoked current, separate from $I_{\mathrm{R}}$ and $I_{\mathrm{S}}$. First, $I_{\mathrm{X}}$ is apparently the only ELH-evoked current that remains in $10 \mathrm{Co} / 0 \mathrm{Ca}$ medium (Fig. 4). Second, the other ELH-evoked currents $\left(I_{\mathrm{SI}}\right.$ and $\left.I_{\mathrm{R}}\right)$ cannot account for the net inward evoked current that occurs in the -70 to $-40 \mathrm{mV}$ range: The inwardly rectifying $\mathrm{K}^{+}$current is outward, not inward, above the reversal potential for $\mathrm{K}^{+}$ions, $-76 \mathrm{mV}$. The isolated $I_{\mathrm{SI}}$ current (Figs. 5,7 ) becomes activated only at membrane potentials above $-40 \mathrm{mV}$. Third, the extrapolated reversal potential of the current evoked below -80 $\mathrm{mV}$ shifts to more positive values as the response to ELH develops (Fig. 9). The onset of a steady inward current $\left(I_{\mathrm{x}}\right)$, but not an inwardly rectifying $\mathrm{K}^{+}$current, would explain such a shift. Other mechanisms that would explain this shift, such as extracellular $\mathrm{K}^{+}$accumulation, were ruled out by holding the cells at $-110 \mathrm{mV}$ for $10 \mathrm{sec}$ before the onset of the ramp.

In addition, an $I_{\mathrm{X}}$-like inward current was reduced or absent in all experiments where the external $\mathrm{Na}^{+}$concentration was reduced (Fig. 8) or eliminated (Fig. 5), and the current remaining 
in $10 \mathrm{Co} / 10 \mathrm{Ca}$ medium and the current that is apparently blocked by $50 \% \mathrm{Na}^{+}$were of comparable size. We therefore conclude that $I_{\mathrm{X}}$ is a third ELH-evoked current that needs external $\mathrm{Na}^{+}$to operate. Although we did not measure a reversal potential for $I_{\mathrm{x}}$, the reversal potential extrapolates to a positive membrane potential. This is consistent with the possibility that $\mathrm{Na}^{+}$is a charge carrier for $I_{\mathrm{x}}$.

An isoprenaline-modulated, $\mathrm{Na}^{+}$-dependent current, with some properties similar to those of $I_{\mathrm{X}}$, has recently been described in ventricular myocytes (Egan et al., 1987). However, as an inward current with a voltage-independent conductance, $I_{\mathrm{x}}$ appears to represent a novel type of current to be modulated by neuropeptides. A current modulated by the neuropeptide LHRH with characteristics similar to those of $I_{\mathrm{X}}$ has been briefly described in the bullfrog sympathetic ganglion (Joncs, 1985).

\section{ELH modulates opposing currents to control neuronal excitability}

Application of ELH or the triggering of a $\mathrm{BCB}$ induces or augments long-lasting repetitive spiking in $\mathrm{LB}$ and $\mathrm{LC}$ neurons (Mayeri et al., 1979b). The currents modulated by ELH are likely to be essential for generating the pacemaker currents that result in repetitive activity, but the relative contributions of the currents are not entirely clear. The currents $I_{\mathrm{X}}$ and $I_{\mathrm{S}}$ provide the depolarizing drive that tends to increase spike rate. The voltageindependent current $I_{\mathrm{x}}$ provides a steady "background" current that is active at all membrane potentials between -110 and $-10 \mathrm{mV}$ and depolarizes the membrane, even at very negative membrane potentials. Although $I_{\mathrm{X}}$ and $I_{\mathrm{SI}}$ are relatively small at resting membrane potentials, the slope of the $I-V$ relation of these ncurons in the -60 to $-30 \mathrm{mV}$ region is small; consequently, relatively small currents can result in large depolarizations (see Figs. 1 and 2).

As a result of its inwardly rectifying $I-V$ relation, $I_{\mathrm{R}}$ is expected to be activated during the undershoot at the end of each spike. Analysis in Figures $6 C$ and $7 A_{2}$ indicates that $I_{\mathrm{R}}$ may already be activated for $25 \%$ at $-60 \mathrm{mV}$, and $I_{\mathrm{R}}$ may therefore contribute to the mechanism of repetitive spiking by prolonging the interval to the next spike, as in Purkinje fibers of the vertebrate heart (Noble and Tsien, 1968). In contrast to $I_{\mathrm{SI}}$ and $I_{\mathrm{X}}$, the $I_{\mathrm{R}}$ would tend to decrease spike rate. Additionally, as mentioned above, we cannot exclude the possibility that ELH may modulate other, transient currents that are involved in spike generation.

\section{ELH as a neurotransmitter}

The present study shows that BCBs and ELH induce apparently identical changes in membrane conductance. This provides additional evidence that ELH is a neurotransmitter. Earlier investigations (see Mayeri et al., 1985) showed that ELH meets almost all of the strict criteria that have been used to identify substances as neurotransmitters (Werman, 1966). This includes synthesis, release, mimicry, and a mechanism for inactivation (which in this case is slow or ineffective). Although a receptor antagonist for ELH is lacking, there is the unusual added evidence that, as a consequence of the neuroendocrine nature of the bag cells, ELH is released in more than sufficient quantities to act as a neurotransmitter within the ganglion (Mayeri et al., 1985). It therefore seems reasonable to conclude that ELH is an identified neurotransmitter. Despite the fact that peptides are now widely accepted as potential neurotransmitters, the number of peptides that have been shown to fulfill the strict criteria for transmitter identification is small. The peptides for which a role as neurotransmitter is most clear include LHRH (Jan and Jan, 1982), substance P (Konishi and Otsuka, 1985), and alpha-bag cell peptide (Rothman et al., 1983a; Sigvardt et al., 1986).

\section{References}

Adrian, R. H. (1969) Rectification in muscle membrane. Prog. Biophys. Mol. Biol. 19: 340-369.

Benson, J. A., and I. B. Levitan (1983) Serotonin increases an anomalously rectifying $\mathrm{K}^{+}$current in the Aplysia neuron R15. Proc. Natl. Acad. Sci. USA 80: 3522-3525.

Branton, W. D., and E. Mayeri (1978) Evidence for local hormonal communication between neurones in Aplysia. Nature 274: 70-72.

Branton, W. D., S. Arch, T. Smock, and E. Mayeri (1978) Evidence for mediation of a neuronal interaction by a behaviorally active peptide. Proc. Natl. Acad. Sci. USA 75: 5732-5736.

Brown, R. O., and E. Mayeri (1986) Evidence for excitatory autotransmission in Aplysia bag cell neurons mediated by alpha-, beta-, and gamma- bag cell peptides. Soc. Neurosci. Abstr. 12: 946.

Cobbs, J. S., and H. M. Pinsker (1982a) Role of bag cells in egg deposition of Aplysia brasiliana. I. Comparison of normal and elicited behaviors. J. Comp. Physiol. 147: 523-535.

Cobbs, J. S., and H. M. Pinsker (1982b) Role of bag cclls in cgg deposition of Aplysia brasiliana. II. Contributions of egg movement to elicited behaviors. J. Comp. Physiol. 147: 527-546.

Deitmer, J. W., and R. Eckert (1985) Two components of Ca-dependent potassium current in identified neurons of Aplysia californica. Pfluegers Arch. 403: 353-359.

Egan, T. M., D. Noble, S. J. Noble, T. Powell, and V. W. Twist (1987) An isoprenaline activated sodium-dependent inward current in ventricular myocytes. Nature 328: 634-637.

Ferguson, G. P., D. W. Parsons, A. ter Maat, and H. M. Pinsker (1986) Spontaneous and elicited bag cell discharges in gonadectomized Aplysia. J. Exp. Biol. 123: 159-173.

Fukushima, Y. (1982) Blocking kinetics of the anomalous rectifier of tunicate egg studied by single channel recording. J. Physiol. (Lond.) 331: $311-331$.

Gay, L. A., and P. R. Stanfield (1977) $\mathrm{Cs}^{+}$causes a voltage-dependent block of inward currents in resting skeletal muscle fibers. Nature 267: 169-170.

Hagiwara, S., and K. Takahashi (1974) The anomalous rectification and cation selectivity of the membrane of a starfish egg cell. J. Membr. Biol. 18: 61-78.

Hagiwara, S., and M. Yoshii (1979) Effects of internal potassium and sodium on the anomalous rectification of the starfish egg as examined by internal perfusion. J. Physiol. (Lond.) 292: 251-265.

Hermann, A., and A. L. F. Gorman (1981) Effects of tetraethylammonium on potassium currents in a molluscan neuron. J. Gen. Physiol. $78: 87-110$.

Iversen, L. L. (1984) Amino acids and peptides: Fast and slow chemical messengers in the nervous system? Proc. R. Soc. London [Biol.] 221: 245-260.

Jan, L. Y., and Y. N. Jan (1982) Peptidergic neurotransmission in the sympathetic ganglia of the frog. J. Physiol. (Lond.) 327: 219-246.

Jansen, R. F., and E. Mayeri (1986) Voltage clamp analysis of responses to egg-laying hormone and alpha-bag cell peptide shows identity with responses to bag cell discharges in Aplysia. Soc. Neurosci. Abstr. 12: 946.

Jansen, R. F., and E. Mayeri (1987) The bag cell peptides alpha-BCP and ELH modulate the excitability of target neurons in the abdominal ganglion of Aplysia. Soc. Neurosci. Abstr. 13: 39.

Jones, S. P. (1985) Muscarinic and peptidergic excitation of bull-frog sympathetic neurones. J. Physiol. (Lond.) 366: 63-87.

Kaneko, A., and M. Tachibana (1985) Effects of L-glutamate on the anomalous rectifier potassium channel in horizontal cells of Carassius auratus retina. J. Physiol. (Lond.) 358: 169-182.

Kauer, J. A., and L. K. Kaczmarek (1986) An inwardly rectifying $\mathrm{K}^{+}$ current in Aplysia is enhanced by a neuropeptide acting at an auto receptor. Soc. Neurosci. Abstr. 12: 149.

Kirk, M. D., and R. H. Scheller (1986) Egg-laying hormone of Aplysia induces a voltage-dependent inward current carried by $\mathrm{Na}^{+}$in an identified neuron. Proc. Natl. Acad. Sci. USA 83: 3017-3021. 
Klein, M., and F. R. Kandel (1980) Mechanism of calcium current modulation underlying presynaptic facilitation and behavioral sensitization in Aplysia. Proc. Natl. Acad. Sci. USA 77: 6912-6916.

Koester, J. H., and E. R. Kandel (1977) Further identification of neurons in the abdominal ganglion of Aplysia using behavioral criteria. Brain Res. 121: 1-20.

Konishi, S., and M. Otsuka (1985) Blockade of slow excitatory postsynaptic potential by substance $P$ antagonists in guinea-pig sympathetic ganglia. J. Physiol. (Lond.) 361: 115-130.

Kramer, R. H., and I. B. Levitan (1986) Calcium influx modulates a cyclic amp-regulated ionic conductance in Aplysia bursting pacemaker neurons. Soc. Neurosci. Abstr. 12: 1001.

Krieger, D. T. (1983) Brain peptides: What, where and why? Science 222: 975-985.

Kunze, D. I.., and A. M. Brown (1971) Internal potassium and chloride activities and the effects of acetylcholine on identifiable Aplysia neurons. Nature [New Biol.] 229: 229-231.

Matsuka, H., ^. Saigusa, and H. Irisawa (1987) Ohmic conductance through the inwardly rectifying $\mathrm{K}$ channel and blocking by internal $\mathrm{Mg}^{2+}$. Nature 325: 156-159.

Mayeri, E., and B. S. Rothman (1982) Nonsynaptic peptidergic neurotransmission in the abdominal ganglion of Aplysia. In Neurosecretion-Molecules, Cells, and Systems, D. S. Farner and K. Lederis, Eds., pp. 307-318, Plenum, New York.

Mayeri, E., P.H. Brownell, and W. D. Branton (1979a) Multiple prolonged actions of neuroendocrine "bag" cells on neurons in Aplysia. I. Effects on bursting pacemaker neurons. J. Neurophysiol. 42:11651184.

Mayeri, E., P. H. Brownell, and W. D. Branton (1979b) Multiple, prolonged actions of neuroendocrine "bag" cells on neurons in Aplysia. II. Effects on beating pacemaker and silent neurons. J. Neurophysiol. 42: 1185-1197.

Mayeri, E., B. S. Rothman, P. H. Brownell, W. D. Branton, and L. Padgett (1985) Nonsynaptic characteristics of neurotransmission mediated by ELH in the abdominal ganglion of Aplysia. J. Neurosci. 5: 2060-2077.

Noble, D. S., and R. W. Tsien (1968) The kinetics and rectifier properties of the slow potassium current in cardiac purkinje fibers. J. Physiol. (Lond.) 195: 185-214.
O'Shea, M., and M. Schaffer (1985) Neuropeptide function: The invertebrate contribution. Annu. Rev. Neurosci. 8: 171-198.

Pinsker, H. M., and F. E. Dudek (1977) Bag cell control of egg-laying in frecly-bchaving Aplysia. Science 197: 490-493.

Ram, J. L. (1983) Neuropeptide activation of an identifiable buccal ganglion motorneuron in Aplysia. Brain Res. 288: 177-186.

Rothman, B.S., E. Mayeri, R. O. Brown, P.-M. Yuan, and J. E. Shively (1983a) Primary structure and neuronal effects of alpha-bag cell peptide, a second candidate neurotransmitter encoded by a single gene in bag cell neurons of Aplysia. Proc. Natl. Acad. Sci. USA 80: 57535757.

Rothman, B.S., G. Weir, and F. E. Dudek (1983b) Direct action of egg-laying hormone on ovotestis of Aplysia. Gen. Comp. Endocrinol. 52: $134-141$

Rothman, B. C., K. A. Sigvardt, and E. Mayeri (1985) Co-release of five peptides, ELH, AP, alpha-, beta-, and gamma-BCP, derived from a common precursor protein of the bag cells of Aplysia. Soc. Neurosci. Abstr. 12: 482.

Scheller, R. H., J. F. Jackson, L. B. McAllister, B. S. Rothman, E. Mayeri, and R. Axel (1983) A single gene encodes multiple neuropeptides mediating a stereotyped behavior. Cell 32: 7-22.

Schmitt, F. O. (1984) Molecular regulators of brain function: A new view. Neuroscience 7:991-1001.

Sigvardt, K. A., B. S. Rothman, R. O. Brown, and E. Mayeri (1986) The bag cells of Aplysia as a multitransmitter system: Identification of alpha bag cell peptide as a second neurotransmitter. J. Neurosci. 6: 803-813.

Stanfield, P. R., Y. Nakajima, and K. Yamaguchi (1985) Substance P raises neuronal excitability by reducing inward rectification. Nature 315: 498-501.

Stuart, D. K., and F. Strumwasser (1980) Neuronal sites of action of a neurosecretory peptide, egg-laying hormone, in Aplysia californica. J. Neurophysiol. 43: 499-519.

Vandenberg, C. A. (1987) Inward rectification of a potassium channel in cardiac ventricular cells depends on internal magnesium ions. Proc. Natl. Acad. Sci. USA 84: 2560-2564.

Werman, R. (1966) Criteria for identification of a central nervous system transmitter. Comp. Biochem. Physiol. 18: 745-766. 